\title{
Impact of body weight gain on hepatic metabolism and hepatic inflammatory cytokines in comparison of Shetland pony geldings and Warmblood horse geldings
}

\author{
Carola Schedlbauer $^{1}$, Dominique Blaue ${ }^{1}$, Martin Gericke ${ }^{2}$, Matthias Blüher ${ }^{3}$, Janine Starzonek ${ }^{1}$, Claudia Gittel $^{4}$, \\ Walter Brehm ${ }^{4}$, Ingrid Vervuert ${ }^{\text {Corresp. } 1}$ \\ ${ }^{1}$ Leipzig University, Institute of Animal Nutrition, Nutrition Disease and Dietetics, Leipzig, Saxony, Germany \\ 2 Leipzig University, Institute of Anatomy, Leipzig, Saxony, Germany \\ 3 Leipzig University, Department of Medicine, Leipzig, Saxony, Germany \\ 4 Leipzig University, Department for Horses, Leipzig, Saxony, Germany \\ Corresponding Author: Ingrid Vervuert \\ Email address: ingrid.vervuert@vetmed.uni-leipzig.de
}

Background. Non-alcoholic fatty liver disease is known as determining part of human obesity. The impact of body weight (BW) gain on liver metabolism has not been extensively investigated yet.

Objectives. To investigate hepatic alterations caused by increasing BW in ponies and horses.

Animals. 19 non-obese equines (10 Shetland ponies, geldings; nine Warmblood horses, geldings).

Methods. Animals received $200 \%$ of their metabolizable maintenance energy requirements for two years. Serum alkaline phosphatase (ALP), glutamate dehydrogenase (GLDH), aspartate aminotransferase (AST), and gamma-glutamyl transferase (GGT) activities and bile acids (BA) were analyzed several times during two years of hypercaloric diet. Hepatic lipid content and hepatic levels of the interleukin (IL)-6, tumor necrosis factor $\alpha(T N F \alpha)$, cluster of differentiation (CD) 68, IL-1 $\beta$, lipoprotein lipase (LPL), fatty acidbinding protein 1 (FABP1), chemerin and nuclear factor $\mathrm{k} B$ (NF-kB) mRNAs were assessed at the start of the study and after one and two years of excess energy intake.

Results. The mean ( \pm SD) BW gain recorded during two years of excess energy intake was $29.9 \pm$ $19.4 \%$ for ponies and $17 \pm 6.74 \%$ for horses. The hepatic lipid content was not profoundly affected by increasing BW. Levels of the IL-6, TNF $\alpha$, CD68 and IL-1 $\beta$ mRNAs did not change during BW gain. Levels of the chemerin mRNA increased significantly in both breeds (ponies: $P=0.02$; horses: $P=0.02$ ) in response to BW gain. Significant differences in serum GLDH and AST activities, serum bile acid concentrations and hepatic levels of the LPL mRNA were observed between ponies and horses at the end of the study.

Conclusions: Chemerin might represent an interesting marker for future equine obesity research. Interestingly, steatosis caused by increasing BW may occur later in the development of obesity in equines than in humans. Additionally, the hepatic metabolism exhibits differences between ponies and horses, which may explain in part the greater susceptibility of ponies to obesity-associated metabolic dysregulations. 


\section{Impact of body weight gain on hepatic metabolism and hepatic}

\section{2 inflammatory cytokines in comparison of Shetland pony geldings}

\section{3 and Warmblood horse geldings}

4 Carola Schedlbauer ${ }^{1}$, Dominique Blaue ${ }^{1}$, Martin Gericke ${ }^{2}$, Matthias Blüher ${ }^{3}$, Janine Starzonek ${ }^{1}$,

5 Claudia Gittel $^{4}$, Walter Brehm ${ }^{4}$ and Ingrid Vervuert ${ }^{1}$

$6{ }^{1}$ Leipzig University, Institute of Animal Nutrition, Nutrition Diseases and Dietetics, Leipzig,

7 Saxony, Germany

$8 \quad{ }^{2}$ Leipzig University, Institute of Anatomy, Leipzig, Saxony, Germany

$9 \quad{ }^{3}$ Leipzig University, Department of Medicine, Leipzig, Saxony, Germany

$10{ }^{4}$ Leipzig University, Department for Horses, Leipzig, Saxony, Germany

12 Corresponding Author

13 PD. Dr. Ingrid Vervuert

14 An den Tierkliniken 9; 04103 Leipzig, Germany

15

16 Email address: Ingrid.vervuert@vetmed.uni-leipzig.de 
18 Abstract

19

Background. Non-alcoholic fatty liver disease is known as determining part of human obesity. The impact of body weight (BW) gain on liver metabolism has not been extensively investigated yet.

Objectives. To investigate hepatic alterations caused by increasing BW in ponies and horses.

Animals. 19 non-obese equines (10 Shetland ponies, geldings; nine Warmblood horses, geldings).

Methods. Animals received 200\% of their metabolizable maintenance energy requirements for two years. Serum alkaline phosphatase (ALP), glutamate dehydrogenase (GLDH), aspartate aminotransferase (AST), and gamma-glutamyl transferase (GGT) activities and bile acids (BA) were analyzed several times during two years of hypercaloric diet. Hepatic lipid content and hepatic levels of the interleukin (IL)-6, tumor necrosis factor $\alpha(\mathrm{TNF} \alpha)$, cluster of differentiation (CD) 68, IL-1 $\beta$, lipoprotein lipase (LPL), fatty acid-binding protein 1 (FABP1), chemerin and nuclear factor $\kappa \mathrm{B}(\mathrm{NF}-\kappa \mathrm{B}) \mathrm{mRNAs}$ were assessed at the start of the study and after one and two years of excess energy intake.

Results. The mean $( \pm \mathrm{SD}) \mathrm{BW}$ gain recorded during two years of excess energy intake was 29.9 $\pm 19.4 \%$ for ponies and $17 \pm 6.74 \%$ for horses. The hepatic lipid content was not profoundly affected by increasing BW. Levels of the IL-6, TNF $\alpha$, CD68 and IL-1 $\beta$ mRNAs did not change during BW gain. Levels of the chemerin mRNA increased significantly in both breeds (ponies: P $=0.02$; horses: $\mathrm{P}=0.02$ ) in response to $\mathrm{BW}$ gain. Significant differences in serum GLDH and AST activities, serum bile acid concentrations and hepatic levels of the LPL mRNA were observed between ponies and horses at the end of the study. 
40 Conclusions: Chemerin might represent an interesting marker for future equine obesity research.

41 Interestingly, steatosis caused by increasing BW may occur later in the development of obesity

42 in equines than in humans. Additionally, the hepatic metabolism exhibits differences between

43 ponies and horses, which may explain in part the greater susceptibility of ponies to obesity-

44 associated metabolic dysregulations. 
46

47

48

49

50

\section{Introduction}

Obesity is an increasing problem in humans and companion animals, such as horses.

Metabolic syndrome (metS) in humans is characterized by the accumulation of different symptoms, namely, obesity, increased circulating triglycerides, reduced high density lipoproteincholesterol concentrations, increased blood pressure and increased fasting glucose levels (Alberti, Zimmet \& Shaw, 2006). Equines develop a similar but not identical symptom complex termed equine metabolic syndrome (EMS), which is defined by obesity, insulin dysregulation and a predisposition towards laminitis (Frank et al., 2010). EMS is furthermore linked to dyslipidemia, hyperleptinemia, arterial hypertension and low-grade inflammation (Frank et al., 2010). Susceptibility to EMS seems to be higher in pony breeds than in most horse breeds (Johnson et al., 2010).

The association between metS and the liver has been studied extensively in humans, as the livers of individuals suffering from metS exhibit frequently a form of steatosis termed nonalcoholic fatty liver disease (NAFLD). Some authors consider NAFLD to be the hepatic manifestation of metS (Cortez-Pinto et al., 1999). On the other hand, NAFLD also appears to be a precursor of metS and type 2 diabetes. Therefore, NAFLD seems to be a risk factor for the development of metS (Lonardo et al., 2015). Among other parameters, NAFLD is characterized by increased serum liver enzyme activities, such as aminotransferases (Sookoian et al., 2016). Hence, elevated serum liver enzyme activities emerged as potential biomarkers of an increased risk for developing metS and its related complications (Devers et al., 2008; Zhang et al., 2015). To the best of the authors' knowledge, the interrelations of equine obesity and the liver have not been studied yet. One study reported serum gamma-glutamyl transferase (GGT) and aspartate aminotransferase (AST) activities that exceeded the reference ranges in obese horses with a 
69 history of laminitis (Chameroy et al., 2011). The authors suggested that hepatic lipidosis caused

70 the changes in liver metabolism.

In addition, high circulating levels of proinflammatory cytokines (e.g., tumor necrosis factor $\alpha$ (TNF $\alpha$ ), interleukin-1 (IL-1), and interleukin-6 (IL-6)), markers of lipid metabolism (e.g., fatty acid-binding protein 1 (FABP1)) and adipokines (e.g., leptin, chemerin) have been reported in equine and human obesity (Vozarova et al., 2001; Bozaoglu et al., 2007; Vick et al., 2007; Shi et al., 2012; $Q u$, Deng \& Hu, 2013). Adipose tissue is thought to be the main site of production of these adipokines (Hotamisligil, Shargill \& Spiegelman, 1993; Arner, 2005; Blüher, 2012) although resident liver macrophages (Kupffer cells) may also play a prominent role (Baffy, 2009). Likewise, chemerin, another potent marker of inflammation, seems to be synthesized in the liver rather than in the visceral adipose tissue of human patients with liver cirrhosis (Weigert et al., 2010). However, researchers have not determined whether hepatic levels of the abovementioned mediators might be affected by equine obesity.

The aim of the present study was to investigate changes in serum liver enzyme activities, serum bile acids (BA), liver lipid content and hepatic mRNA levels of several markers of inflammation and lipid metabolism in the course of increasing body weight (BW) in equines. The comparison of Shetland ponies and Warmblood horses should elucidate the underlying reasons for the higher predisposition of pony breeds to metabolic derangements. We hypothesized that equine obesity is associated with hepatic alterations. Furthermore, we expected that liver metabolism exhibits different responses between ponies and horses during long-term excess energy intake.

\section{Materials and methods}

\section{Animals}


93 Warmblood horses (geldings; mean age $10 \pm 3$ years, E. caballus) owned by the Institute of

94

Animal Nutrition, Nutrition Diseases and Dietetics of the Leipzig University were included in the study. All animals were supposed to be adult, therefore we included equines older than 3 years and younger than 15 years. We decided to use only geldings to exclude the influence of gender related differences such as the sexual cycle in mares. Prior to the study, pituitary pars intermedia dysfunction was excluded by measuring ACTH levels after 8 hours of fasting. An experienced clinician (CG) confirmed the absence of clinical or radiological signs of previous or acute laminitis of the front feet in all animals. The animals were bedded on straw in individual box stalls and were turned out onto a dry lot for approximately 5 hours a day. The animals were adapted to the experimental conditions for at least 2 weeks. The Ethics Committee for Animal Rights Protection of the Leipzig District Government (No. TVV 32/15) approved the project in accordance with German legislation for animal rights and welfare. Animals were cared for according to the guidelines for the accommodation and care of animals used for experimental and other scientific purposes $(2007 / 526 / \mathrm{EC})$.

\section{Study design}

The study was conducted from October 2015 until December 2017. Ponies and horses initially received meadow hay and a commercial mineral supplement to meet or exceed their energy and nutrient requirements during maintenance according to the guidelines of the Society of Nutrition Physiology (GfE 2014) (Flachowsky et al., 2014). The basal state of the animals was assessed in October 2015 (t0) by examination of serum liver enzyme activities, serum BA, serum amyloid A (SAA), plasma glucose, serum insulin, serum triglycerides (TG), serum non-esterified fatty acids (NEFA) concentrations, by conduction of a combined glucose insulin test (CGIT) 
115 (Eiler et al., 2005) and by liver tissue sampling. Following the collection of these initial data, the

116 animals underwent a feeding period by receiving $200 \%$ of their metabolizable energy (ME)

117 maintenance requirements according to the GfE (2014) under conditions of gradual adaptation

118 (Flachowsky et al., 2014). 60\% percent of the energy intake was supplied by hay, and 40\% was

119 provided by a concentrate (Pavo Pferdenahrung GmbH, Vechta Langförden, Germany). For

120 dietary intake of nutrients and intake of ME see table 1. BW, body condition score (BCS) and

121 cresty neck score (CNS) were monitored weekly. Energy intake was adapted monthly to the

122 current BW. During the feeding period further data were collected in July $2016(\mathrm{t} 1)$, October

1232016 (t2), April 2017 (t3), July 2017 (t4) and December 2017 (t5). At all time points blood

124 samples were obtained for assessments of serum liver enzyme activities and serum BA. In

125 addition to t0, SAA, plasma glucose, serum insulin, serum TG and serum NEFA concentrations

126 were analyzed at $\mathrm{t} 2$ and $\mathrm{t} 5$. Additionally, at $\mathrm{t} 2$ and $\mathrm{t} 5$ the insulin sensitivity was assessed by

127 performing a CGIT (Eiler et al., 2005) and a lipopolysaccharide (LPS) challenge was conducted

128 followed by liver tissue sampling 15 hours later.

\section{Blood sampling}

130 Blood samples for assessment of serum insulin, SAA, serum NEFA, serum TG and

131 plasma glucose concentrations were collected at $\mathrm{t} 0, \mathrm{t} 2$ and $\mathrm{t} 5$. Blood samples for analysis of

132 serum liver enzyme activities and serum BA concentrations were obtained at $\mathrm{t} 0, \mathrm{t} 1, \mathrm{t} 2, \mathrm{t} 3$, $\mathrm{t} 4$ and

133 t5. After 8 hours of fasting, a 14-gauge-catheter (Milacath, Mila International, Florence, KY,

134 USA) was aseptically placed into the jugular vein of ponies and horses. Blood samples were

135 collected in tubes containing coagulation activator (Monovette, Sarstedt AG, Nuembrecht,

136 Germany) and centrifuged at $865 \times \mathrm{g}$ for $10 \mathrm{~min}$ after $30 \mathrm{~min}$ of clotting time for assessments of

137 serum insulin levels, liver enzyme activities, BA, SAA, NEFA and TG concentrations. Blood 
138 samples for plasma glucose assessments were collected in tubes containing sodium fluoride (S-

139 Monovette, Sarstedt AG, Nuembrecht, Germany) and immediately centrifuged at $865 \times \mathrm{g}$ for 10

$140 \mathrm{~min}$. Serum and plasma samples were gradually frozen from $-20^{\circ} \mathrm{C}$ to $-80^{\circ} \mathrm{C}$ and stored at $-80^{\circ} \mathrm{C}$

141 until analysis.

142 CGIT

143 The CGIT was conducted at $\mathrm{t} 0, \mathrm{t} 2$ and $\mathrm{t} 5$ and consisted of rapid IV administration of 150

$144 \mathrm{mg} / \mathrm{kg} \mathrm{BW}$ of glucose (40\% anhydrous glucose, WDT, Garbsen, Germany) and 0.1 U/kg BW of

145 insulin (Humulin R, Lilly USA, Indianapolis, USA) mixed with $3 \mathrm{~mL}$ of $0.9 \%$ saline as adapted

146 from Eiler et al. (2005). Blood samples were collected before and 1, 5, 15, 25, 35, 45, 60, 75, 90,

$147105,120,135$, and 150 min after insulin injection in tubes containing sodium fluoride (S-

148 Monovette, Sarstedt AG, Nuembrecht, Germany) or a coagulation activator (Monovette, Sarstedt

149 AG, Nuembrecht, Germany). Tubes containing a coagulation activator were centrifuged after a

150 clotting time of $30 \mathrm{~min}$, whereas tubes containing sodium fluoride were immediately centrifuged

151 at $865 \mathrm{x}$ g for $10 \mathrm{~min}$. Plasma and serum samples were aliquoted and gradually frozen from -

$15220^{\circ} \mathrm{C}$ to $-80^{\circ} \mathrm{C}$.

153 LPS challenge

154 The LPS challenge was performed 3-5 days after initial blood sampling. A 14-gauge-

155 indwelling catheter (Milacath, Mila International, Florence, KY, USA) was aseptically inserted

156 into the jugular vein. LPS (Escherichia coli 055:B5, $1000 \mathrm{ng} / \mathrm{mL}$, Sigma-Aldrich Chemie

$157 \mathrm{GmbH}$, München, Germany) (diluted in $500 \mathrm{~mL} / 1000 \mathrm{~mL}$ of $0.9 \%$ saline for the ponies/horses)

158 was infused at a dosage of $10 \mathrm{ng} / \mathrm{kg} \mathrm{BW}$ over $30 \mathrm{~min}$. The animals were monitored for 3 hours,

159 using a modified pain score described by Bussieres et al. (2008), which grades 13 different

160 parameters on a scale from 0 (physiologic) to 3 (pathologic). Examined parameters were for 
161 example the rectal temperature, appetite and abdominal discomfort. 14 hours after the LPS

162 infusion, blood samples were collected in tubes containing coagulation activator (Monovette,

163 Sarstedt AG, Nuembrecht, Germany) for SAA determination. The tubes were centrifuged at 865

$164 \mathrm{x}$ g for 10 min after 30 min of clotting time. Serum was harvested and gradually frozen from -

$16520^{\circ} \mathrm{C}$ to $-80^{\circ} \mathrm{C}$.

166 Liver tissue sampling

167 The animals were sedated with $0.04 \mathrm{mg} / \mathrm{kg} \mathrm{BW}$ romifidine (Sedivet ${ }^{\circledR}$, Boehringer

168 Ingelheim Pharma GmbH \& Co. KG, Ingelheim am Rhein, Germany) and 0.03 mg/kg BW

169 butorphanol (Alvegesic ${ }^{\circledR}$, CP-Pharma Handelsgesellschaft GmbH, Burgdorf, Germany) 15 hours

170 after the LPS challenge. Diazepam at a dose of $0.08 \mathrm{mg} / \mathrm{kg} \mathrm{BW}$ (Diazepam-Lipuro ${ }^{\circledR}$, Laboratoire

171 TVM, Lempdes, France) and $3 \mathrm{mg} / \mathrm{kg} \mathrm{BW}$ ketamine (Ursotamin ${ }^{\circledR}$, Serumwerk Bernburg AG,

172 Bernburg, Germany) were administered to induce general anesthesia. Inhalation anesthesia was

173 maintained with isoflurane (CP-Pharma Handelsgesellschaft GmbH, Burgdorf, Germany). A 20-

$174 \mathrm{~cm}$ ventral midline incision was performed cranial to the umbilicus after aseptic preparation.

175 Liver tissue ( $2 \mathrm{~g}$ ) was collected using biopsy forceps. Additionally, adipose tissue was collected

176 from several locations for another part of the study. One part of each tissue biopsy specimen was

177 immediately flash frozen in liquid nitrogen $\left(-196^{\circ} \mathrm{C}\right)$ and stored at $-80^{\circ} \mathrm{C}$. The second part was

178 stored in formalin. The animals were orally administered $0.55 \mathrm{mg} / \mathrm{kg} \mathrm{BW}$ flunixin twice a day for

179 three days after surgery (Flunidol ${ }^{\circledR}, \mathrm{CP}-\mathrm{Pharma}$ Handelsgesellschaft GmbH, Burgdorf,

180 Germany).

181

182

183

\section{Determination of BW}

BW was obtained weekly using an electronic scale system for large animals (scale system: Iconix FX 1, Texas Trading, scale precision: $0.5 \mathrm{~kg}$ ).

PeerJ reviewing PDF | (2019:01:34571:1:1:NEW 16 Apr 2019) 
184

185

186

187

188

189

190

191

192

193

194

195

196

197

198

199

200

201

202

203

204

205

206

\section{BCS and CNS}

BCS (Carroll \& Huntington, 1988) and CNS (Carter et al., 2009a) were assessed on a scale ranging from 0 to 5 points. BCS and CNS were graded weekly by two independent

evaluators (CS and DB). A mean of these two evaluators was calculated.

\section{Analysis of blood samples}

Plasma ACTH levels were analyzed by a commercial laboratory using a

chemiluminescence immunoassay (IDEXX GmbH, Ludwigsburg, Germany).

Serum liver enzyme activities [alkaline phosphatase (ALP), glutamate dehydrogenase

(GLDH), AST, and GGT] and serum BA, TG and NEFA concentrations were analyzed using an automated chemistry analyzer (Roche Cobas C311, Roche Diagnostic GmbH, Mannheim, Germany).

SAA levels were determined by turbidimetry (ABX Pentra 400 analyzer, ABX Horiba, Axonlab, Montpellier, France).

Plasma glucose concentrations were determined using the GOD/POD method. Serum insulin levels were analyzed using an immunoradiometric assay (IRMA, 125I,

Demeditec Diagnostics GmbH, Kiel, Germany).

\section{Histological staging of hepatic steatosis}

Hematoxylin-eosin staining was routinely performed on all liver biopsies and analyzed by an experienced histologist (MG). Steatosis was graded as follows: $<5 \%$ lipid content of liver parenchyma: $0 ; 5-33 \%: 1 ;>33-66 \%: 2 ;>66 \%: 3$.

\section{Analysis of hepatic mRNA levels}

RNA was isolated using a commercial kit (RNeasy Lipid Tissue Mini Kit and Qiacube, Qiagen, AMBION, Inc., USA) according to the manufacturer's protocol. The RNA concentration 
207 was measured with a spectrophotometer (NanoVue ${ }^{\circledR}$ Plus, Healthcare Biosciences AB,

208 München, Germany). RNA quality was determined using an Agilent 2100 Bioanalyzer (Agilent

209 Technologies, Santa Clara, United States). Two micrograms of RNA were transcribed into

210 cDNAs in a thermocycler (Engine Peltier Thermal Cycler, Bio-Rad Laboratories GmbH,

211 München, Germany) using two master mixes: (1) random primers and dNTP and (2) SuperScript

212 II RT, 5x First Strand Buffer, and 0.1 M DTT (Thermo Fisher Scientific Inc., Schwerte,

213 Germany). The genes of interest were IL-1 $\beta$, IL-6, TNF $\alpha$, cluster of differentiation 68 (CD68),

214 chemerin, nuclear factor- $\kappa \mathrm{B}(\mathrm{NF}-\kappa \mathrm{B})$, lipoprotein lipase (LPL) and FABP1. The 18S rRNA,

215 hypoxanthine phosphoribosyltransferase 1 (HPRT1) and ribosomal protein L32 (RPL32) were

216 chosen as reference genes (see table 2 for primer sequences). Reference gene mRNAs were not

217 altered by BW gain (Pfaffl et al., 2004). An RNA-probe was used for 18S rRNA quantification.

218 A standard Taqman program (7500 Real Time PCR System, Thermo Fisher Scientific Inc.,

219 Schwerte, Germany) was performed for qPCR, with minor modifications. Two master mixes

220 were utilized: Power SYBR Green PCR Master Mix for the genes detected with primers and

221 Taqman Universal PCR Master Mix for the 18S RNA (Thermo Fisher Scientific Inc., Schwerte,

222 Germany). The genes of interest were normalized to the geometric means of the three reference 223 genes 18S, HPRT1 and RPL32.

\section{Statistics}

225 The data were analyzed using a statistical software program (STATISTICA, version 12, RRID:SCR_014213, StatSoft GmbH, Hamburg, Germany). The data were analyzed for normal

227 distributions using the Shapiro-Wilks test. ANOVA with repeated measurements was performed to analyze plasma glucose, serum insulin, serum TG and serum NEFA concentrations. Fisher's

229 Least Significant Difference test was performed to identify significant differences. BCS, CNS, 
230 serum liver enzyme activities, serum BA concentrations, liver lipid content and mRNA levels of

231 genes of interest were analyzed using nonparametric tests. Friedman's ANOVA was used to

232 analyze the effect of time. When significant differences were observed, the Wilcoxon signed

233 rank test with Bonferroni's correction was performed as post hoc test. The effects of the breed on

234 nonparametric data were analyzed using the Mann-Whitney U test. Correlations among variables

235 were examined by calculating Spearman's correlation coefficients. Pain score values of each

236 parameter at LPS challenge were added and described descriptively. Statistical significance was

237 set to $\mathrm{P}<0.05$.

238 Results

239

Prior to the initiation of excess energy intake, all animals were assessed as metabolically

healthy, according to the ACTH concentrations and results of the CGIT.

241

The two years of excess energy intake caused a significant increase in mean BW $( \pm \mathrm{SD})$

242

of $29.9 \pm 19.4 \%$ for ponies $(\mathrm{P}=0.0002)$ and $17 \pm 6.74 \%(\mathrm{P}=0.00004)$ for horses. Throughout

the study, no significant differences in BW gain (\%) could be found between the breeds. One

pony developed an episode of laminitis during the second year of excess energy intake.

Therefore, final samples were collected before the end of the study (July 2017) after complete

recovery of clinical signs (pounding digital pulse, lameness). The pony received opioids once for

247 pain relief 7 days before data collection. Laminitis occurred additionally in one horse at the end

248 of the second year of excess energy intake. This horse received non-steroidal anti-inflammatory with the study design in the laminitic horse. No clinical signs of laminitis were present at this point. One pony developed hyperlipemia (serum TG: $14.4 \mathrm{mmol} / \mathrm{L}$ ) at the end of the second year

252 of excess energy intake beside good appetite. The pony was carefully monitored (e.g. appetite, 
253 behavior, lameness) and the pony recovered without medication within 14 days. Samples were

254 collected after serum TG concentrations returned to the baseline value. The animals did not

255 suffer from additional health problems due to excess nutrition such as colic. BCS and CNS

256 increased significantly in ponies and horses during the two years of excess energy intake (table

257 3). No significant differences in BCS and CNS were observed between the breeds. The CNS of

258 the laminitic pony (4.5 points) was greater than the median of the respective cohort at $\mathrm{t} 5$,

259 whereas the CNS of the laminitic horse (3 points) remained within the median of the respective

260 cohort. The BCS and CNS of the lipemic pony were within the median of the cohort of the

261 ponies (BCS: 3.75; CNS: 4).

Plasma glucose and serum NEFA concentrations were significantly lower in ponies

263 compared to horses at t0. With BW gain plasma glucose and serum NEFA concentrations

264 increased in ponies, but not in horses. No significant differences between the breeds were

265 observed at $\mathrm{t} 2$ and $\mathrm{t} 5$ concerning these parameters (table 4). Basal serum insulin concentrations

266 increased significantly in both breeds from t0 to t5. The ponies showed significantly higher

267 serum TG concentrations than horses at $\mathrm{t} 0$ and $\mathrm{t} 2$ (table 4). Mean SAA concentrations in ponies

268 and horses were below the reference range of $2.7 \mu \mathrm{g} / \mathrm{mL}$ at all three data collection points.

269 The sum of pain score points increased subsequently to the LPS infusion in the animals

270 from basal mean values $(\mathrm{t} 0: 1.4 ; \mathrm{t} 2: 0.5 ; \mathrm{t} 5: 1.5)$ to mean maximum values $(\mathrm{t} 0: 6.1 ; \mathrm{t} 2: 6.7 ; \mathrm{t} 5$ :

271 6.1). Mean maximum values were reached 60 minutes after the LPS infusion at $\mathrm{t} 0$ and $\mathrm{t} 2$ and 30

272 minutes after the LPS infusion at $\mathrm{t} 5$.

\section{Serum liver enzyme activities}

Serum ALP and GGT activities were significantly decreased in ponies after one year of excess energy intake. In ponies, serum GLDH activity and BA concentrations increased 
276 significantly from to to t5. Furthermore, significantly higher serum GLDH activities ( $\mathrm{t} 0: \mathrm{P}=$

277 0.04; $\mathrm{t} 1: \mathrm{P}=0.00002 ; \mathrm{t} 2: \mathrm{P}=0.02 ; \mathrm{t} 3: \mathrm{P}=0.00002 ; \mathrm{t} 4: \mathrm{P}=0.001)$, serum AST activities $(\mathrm{t} 1: \mathrm{P}=$

$2780.0007 ; \mathrm{t} 2: \mathrm{P}=0.003 ; \mathrm{t} 3: \mathrm{P}=0.001 ; \mathrm{t} 4: \mathrm{P}=0.02)$ and $\mathrm{BA}$ concentrations $(\mathrm{t} 1: \mathrm{P}=0.0004 ; \mathrm{t} 3: \mathrm{P}=$

$2790.001 ; \mathrm{t} 4: \mathrm{P}=0.03 ; \mathrm{t} 5: \mathrm{P}=0.03)$ were observed in ponies compared to horses. The horses

280 showed no significant increases in serum liver enzyme activities but exhibited a significant

281 decrease in serum ALP activity from t0 to t5 (Fig. 1). Serum ALP activity, BA concentrations

282 and GGT activity increased in the lipemic pony during the two years of excess energy intake

283 (ALP: 6.2-fold increase; BA: 6-fold increase; GGT: 2.3-fold increase). Serum liver enzyme

284 activities and BA concentrations in the laminitic equines remained within the reference ranges,

285 (Köller, Gieseler \& Schusser, 2014) except for serum GGT activity at t5 in the laminitic pony

$286(\mathrm{GGT}=73.1 \mathrm{U} / \mathrm{L})$.

\section{Histological staging of steatosis}

At 15 the percentage of individuals exhibiting a hepatic lipid content of more than 5\%

increased in ponies and decreased in horses. However, the majority of ponies and horses showed

a constant steatosis grade 0 (table 5). The pony suffering from hyperlipemia showed stage 3

steatosis, with more than 66\% lipid-loaded hepatocytes at t5 (steatosis stage at t0: 0 ). Both

laminitic equines steatosis stage 0 at t 0 . The laminitic horse stayed at steatosis stage 0 throughout the study, but the laminitic pony showed steatosis stage 1 at $\mathrm{t} 5$.

\section{Hepatic mRNA levels of genes of interest}

Levels of the TNF $\alpha$, IL-6, FABP1 and CD68 mRNAs were not significantly altered in

ponies and horses throughout the observation period. Hepatic levels of the chemerin mRNA 
299 level of the chemerin mRNA from t0 to $t 5$ and from t 2 to $t 5$ (Fig. 2). Levels of the NF- $\kappa$ B mRNA

300 decreased significantly in horses from $\mathrm{t} 2$ to $\mathrm{t} 5(\mathrm{P}=0.02)$ and remained unchanged in ponies

301 throughout the study. Regarding the breed-specific differences, the ponies showed significantly

302 higher hepatic levels of the LPL $(P=0.005)$, NF- $\mathrm{B}(\mathrm{P}=0.01)$ and IL-1 $(\mathrm{P}=0.045)$ mRNAs

303 compared with the horses at $\mathrm{t} 5$. The lipemic pony showed a higher level of the LPL mRNA than

304 the median of the pony cohort (t0: 3.1-fold higher; $\mathrm{t} 2$ : 2-fold higher; $\mathrm{t} 5$ : 2.5 -fold higher) at all

305 time points. Furthermore, the level of FABP1 mRNA was 2.5 -fold higher at t5 compared to the

306 median of the pony cohort. No further notable deviations in the levels of the genes of interest in

307 the laminitic and lipemic equines from the median values of the cohort were observed.

308 Significant correlations between the level of the LPL mRNA and serum BA, the hepatic

309 lipid content and level of the CD68 mRNA were analyzed. Levels of the chemerin mRNA

310 displayed significant correlations with the BCS, CNS and level of the NF- $\kappa \mathrm{B}$ mRNA (table 6). In

311 ponies, a negative correlation was identified between serum ALP activity and age $(\mathrm{r}=-0.4 ; \mathrm{P}=$

312 0.01). No significant correlation between serum ALP activity and age was detected in horses.

\section{Discussion}

Previous studies of equines have been conducted to evaluate the impact of obesity on metabolic characteristics and inflammatory markers in adipose tissue (Vick et al., 2007; Burns et al., 2010). To the best of the authors' knowledge, this study is the first to investigate obesity associated hepatic alterations in equines. The study design was further applied to compare ponies and horses during a long-term feeding period of excess energy intake. However, in comparison with previous studies (Carter et al., 2009b; Siegers et al., 2018) our equines gained less BW 
322 the energy intake in the present study was covered by $40 \%$ concentrate and $60 \%$ roughage.

323 Therefore, the diet of the present study contained less starch and more fibre in comparison to the

324 aforementioned studies. These varying diet compositions may have caused the differences in BW

325 gain. We have used this type of diet (1) for welfare reasons during a long-term observation

326 period and (2) its closer relation to practical feeding regimens.

In humans, steatosis is considered a hepatic manifestation of metS. A standardized

328 procedure for assessment of liver fat content is important, as the hepatic lipid content may vary

329 between different hepatic regions. In the present study, liver sampling was conducted at the same

330 site at the three data collection time points by laparotomy. Using this method, a standardized

331 follow-up of the same area of the liver was possible. But, sampling of liver tissue in vivo is

332 always restricted to a small hepatic region. However, in cows, the liver fat content differed less

333 than $2 \%$ between different liver lobes, suggesting a homogenous distribution of fat (Gerspach et

334 al., 2017). In consequence, the used liver sampling procedure is likely to provide reliable insight

335 in hepatic fat storing in obesity. According to our hypothesis, the percentage of ponies exhibiting

336 a hepatic lipid content of more than 5\% increased from $20 \%$ at t0 to $40 \%$ at the end of the study.

337 But unexpected, the percentage of horses with hepatic lipid content of less than 5\% increased

338 from $67 \%$ at t0 to $89 \%$ at the end of the study. These results are in line with findings in NEFA

339 concentrations, which increased during the study in ponies but not in horses. As $60-80 \%$ of liver

340 stored lipid is derived by circulating free fatty acids, the differences of NEFA concentrations

341 between ponies and horses might have contributed to breed related differences in steatosis stages.

342 The results of serum NEFA concentrations are described in detail by Blaue et al. (2019).

343 Concluding, ponies seem to be more susceptible to hepatic lipid accumulations in early stages of

344 obesity according to the histological evaluation. Furthermore, we speculated that horses might 
345 not develop a steatotic liver in association with early obesity in contrast to humans. Healthy

346 humans showing a BW gain of 5-15\% significantly increased the liver fat content by 2.5 -fold

347 within four weeks (Kechagias et al., 2008), highlighting the profound differences between

348 equine and human metabolism. However, differences might be explained by the 3.5 -fold higher

349 relative daily intake of fat in humans (Kechagias et al., 2008) compared to our equines.

350 Accordingly, Meijer et al. (2010) showed that the dietary fat content itself, independent from

351 caloric intake, was a detrimental factor in the development of steatosis in mice. Despite the

352 differences between ponies and horses, the majority of our equines did not develop steatosis

353 within two years of BW gain. It has been described in Shetland ponies that subcutaneous tissue

354 expandability is limited, while the expansion of the retroperitoneally adipose tissue proceeds

355 (Siegers et al., 2018). It is one possible explanation that the expandability limit of the

356 subcutaneous adipose tissue was not reached in the present study and therefore, fat was not

357 stored extraordinary in retroperitoneal and intraabdominal sites like the liver. The individual

358 pony which developed hyperlipemia in the present study increased steatosis from stage 0 at t0 to

359 stage 3 at the end of the study. Interestingly, this pony did not show the most prominent increase

360 in BW, BCS or CNS. However, the question of whether the liver was steatotic before the onset

361 of hyperlipemia or whether the lipid mobilization caused the elevated hepatic lipid content

362 remained open.

363 The levels of the LPL and FABP1 mRNAs in the liver were determined to elucidate the

364 role of hepatic fat metabolism in obesity. Pardina et al. (2009) described a significant increase in

365 hepatic LPL mRNA levels in obese humans compared to healthy controls. The authors

366 postulated that these changes contributed to the hepatic accumulation of TG, which favors

367 steatosis. Accordingly, we identified a positive correlation between the hepatic level of the LPL 
368 mRNA and the hepatic lipid content in ponies. At t5, ponies showed a 2.4-fold higher level of the

369 LPL mRNA compared to horses. We speculated that ponies may develop an increased risk of

370 steatosis in cases of continuing the long-term excess energy intake. Data of increasing steatosis

371 grade in the liver of ponies supported this assumption. FABP1 is known to facilitate the

372 intracellular trafficking of long-chain fatty acids (Glatz, Van der Vusse \& Veerkamp, 1988). The

373 level of the FABP1 mRNA is increased in humans with steatosis, probably as a compensatory

374 mechanism for increased fat influx (Higuchi et al., 2011). Therefore, our expectation that the

375 level of the FABP1 mRNA in mostly nonsteatotic equines would be unaltered was confirmed.

376 Interestingly, the lipemic pony showed a three-fold elevation in the level of the LPL mRNA at t0

377 compared to the median of the ponies at $\mathrm{t} 0$. We speculated that the pony was already predisposed

378 to developing a steatotic liver, even in the lean body condition. In this pony, high LPL mRNA

379 level was maintained until t5, with 2.5-fold higher levels than the median of the ponies at the end 380 of the study. Additionally, the pony showed a 2.5-fold higher level of the FABP1 mRNA than 381 the median of the ponies at the end of the study, probably due to metabolic demands caused by

382 high fat influx in the liver.

383 Besides liver lipid content, liver enzyme activities represent useful markers for hepatic 384 metabolism. Serum ALP and GGT activities, exhibited either a significant decrease or remained 385 unchanged in the present study. Serum ALP activities showed a significant decrease during the 386 study in ponies and horses. According to Gehlen, May \& Venner (2010), elevated serum ALP 387 activities might be associated with increased bone turnover in young horses. Therefore, changes 388 in ALP activities in ponies and horses might be explained by age-related effects. Serum GLDH 389 activity has interesting properties as marker of liver diseases, as GLDH is a liver-specific 390 enzyme that is mainly located in the mitochondria in the centrolobular hepatocytes (Schmidt \& 
391 Schmidt, 1988). We observed a significant increase in serum GLDH activity in the ponies from

392 t0 to t5, but not in the horses. Serum GLDH activities in the ponies were 2.4-fold higher than the 393 upper reference range of 8.9 U/L (Köller, Gieseler \& Schusser, 2014) at the end of the study.

394 Similar to serum GLDH activities the ponies showed a significant increase in serum BA

395 concentrations from t0 to t5. However, most of the ponies showed serum BA concentrations that 396 remained within the reference range at the end of the study. While BA have long been known to 397 mediate nutrient absorption, BA have recently emerged as signaling molecules for lipid and 398 glucose metabolism (Ma \& Patti, 2014). Furthermore, plasma BA levels were shown to exhibit 399 positive correlations with insulin resistance and type 2 diabetes in humans (Haeusler et al., 400 2013). Therefore, BA are not only a sensitive marker of liver diseases but also an important 401 marker of metS and NAFLD. As further noninvasive marker, serum AST activities are increased 402 in patients with NAFLD (Sookoian et al., 2016). In the present study, ponies showed significant 403 higher serum AST activities compared to horses at four time points. As changes of serum GLDH 404 activity and serum BA during BW gain occurred in ponies but not in horses and serum AST 405 activities were higher in ponies than in horses, it is speculated that the liver of ponies was more 406 affected by early obesity compared to horses.

407 Serum GGT activity of the laminitic pony exceeded the reference range at the end of the study.

408 Accordingly, Chameroy et al. (2011) observed elevated serum GGT activities in $64.3 \%$ of obese 409 horses with a history of laminitis. In addition, the steatosis stage of the laminitic pony increased 410 from stage 0 at t0 to stage 1 at 15 . In contrast, the laminitic horse showed neither an increase in 411 serum liver enzyme activities nor an increase in hepatic lipid content during the study. We determined the hepatic mRNA levels of proinflammatory cytokines to investigate 413 whether the liver contributed to low-grade inflammation concomitant to obesity (Vick et al., 
414 2007). The most prominent change in hepatic mRNA levels as BW increased was found for

415 chemerin. Chemerin has been identified as an adipokine in mouse, rat and human adipocytes

416 (Bozaoglu et al., 2007; Goralski et al., 2007) and has a regulatory role in adipogenesis and

417 adipocyte metabolism (Goralski et al., 2007). In addition to adipose tissue, chemerin is expressed

418 in the liver as well (Pohl et al., 2017). Although substantial experimental evidence supports a

419 proinflammatory role for chemerin (Weigert et al., 2010; Chakaroun et al., 2012; Döcke et al.,

420 2013), other studies have suggested that chemerin might have anti-inflammatory properties

421 (Cash et al., 2008; Luangsay et al., 2009). Consistent with these equivocal results, discrepancies

422 exist regarding the association of chemerin and NAFLD. According to Deng et al. (2013),

423 rodents with NAFLD displayed decreased hepatic levels of the chemerin mRNA compared to

424 control rodents without NAFLD. In contrast, the consumption of a high-fat diet increased hepatic

425 mRNA levels of chemerin in mice compared to animals fed a standard diet (Krautbauer et al.,

426 2013). Unfortunately, the authors did not provide information about the fat content of the diet.

427 Additionally, the chemerin mRNA levels tended to be higher in the liver of humans with

428 NAFLD (Krautbauer et al., 2013). These contradictory findings might be explained by the

429 various pathways in which chemerin is involved. After secretion, chemerin is converted into

430 proinflammatory or anti-inflammatory peptides by different proteases, as reviewed by Yoshimura

$431 \&$ Oppenheim (2008). To date, a study investigating chemerin has not been performed in

432 equines. In the present study, the hepatic level of the chemerin mRNA increased significantly

433 during two years of excess energy intake in ponies and horses. In contrast to the upregulation of

434 chemerin, other proinflammatory factors, such as CD68, TNF $\alpha$, IL-6, and IL-1 $\beta$, were not

435 different between lean and obese equines. Notably, we observed a significant negative

436 correlation between hepatic levels of the chemerin and NF- $\kappa \mathrm{B}$ mRNAs in horses but not in 
437 ponies. NF- $\mathrm{BB}$ is a well-known activator of the transcription of proinflammatory cytokines. This

438 result highlights a possible anti-inflammatory role for chemerin. In this context, Pohl et al.

439 (2017) found a downregulation of the chemerin mRNA levels in livers of humans suffering from

440 a progressive form of NAFLD compared to humans suffering from steatosis alone.

441 Consequently, chemerin represents a potentially interesting marker for obesity associated hepatic

442 alterations and should be the focus of future studies in equines. A limitation of this study was

443 that changes in chemerin levels were not verified at the protein level.

\section{Conclusion}

We detected significant differences in parameters such as serum GLDH and AST activities, serum BA concentrations and levels of the LPL mRNA between ponies and horses.

447 According to our hypothesis, these differences suggested that ponies may show a more

448 pronounced dysregulation of hepatic metabolism in reaction to the early stages of obesity compared to horses. However, in contrast to our hypothesis, liver steatosis seemed not to be an

450 integral part of the early stages of obesity, especially in horses, and may occur in ongoing equine 451 obesity. Liver mRNA levels of well-established proinflammatory cytokines such as TNF $\alpha$ or IL4526 were not significantly upregulated in response to increasing BW. However, chemerin was 453 identified as a potentially novel marker of the hepatic changes associated with obesity in equines.

454 A longer period of BW gain or a higher degree of obesity might be necessary to obtain more 455 significant findings for inflammation and steatosis in the liver.

\section{Acknowledgements}


461 References

462 Alberti KGMM, Zimmet P, Shaw J. 2006. Metabolic syndrome-a new world-wide definition. A

463

464

465

466

467

468

469

470

471

472

473

474

475

476

477

478

479

480

481

482

483

484

485

486

487

488

489

490

491

492

493

494

495

496

497

498

499

500 Consensus Statement from the International Diabetes Federation. Diabetic medicine 23:469-480.

Arner P. 2005. Insulin Resistance in Type 2 Diabetes - Role of the Adipokines. Current Molecular Medicine 5 (3):333-339.

Baffy G. 2009. Kupffer cells in non-alcoholic fatty liver disease: The emerging view. Journal of hepatology 51 (1):212-223.

Blaue D, Schedlbauer C, Starzonek J, Gittel C, Brehm W, Einspanier A, Vervuert I. 2019. Effects of body weight gain on insulin and lipid metabolism in equines. Domestic animal endocrinology (accepted).

Blüher M. 2012. Clinical relevance of adipokines. Diabetes \& metabolism journal 36 (5):317-327.

Bozaoglu K, Bolton K, McMillan J, Zimmet P, Jowett J, Collier G, Walder K, Segal D. 2007. Chemerin is a novel adipokine associated with obesity and metabolic syndrome. Endocrinology 148 (10):46874694.

Burns TA, Geor RJ, Mudge MC, McCutcheon L, Hinchcliff KW, Belknap JK. 2010. Proinflammatory cytokine and chemokine gene expression profiles in subcutaneous and visceral adipose tissue depots of insulin-resistant and insulin-sensitive light breed horses. Journal of veterinary internal medicine $\mathbf{2 4}$ (4):932-939.

Bussieres G, Jacques C, Lainay O, Beauchamp G, Leblond A, Cadore JL, Desmaizieres LM, Cuvelliez SG, Troncy E. 2008. Development of a composite orthopaedic pain scale in horses. Research in veterinary science 85 (2):294-306.

Carroll CL, Huntington PJ. 1988. Body condition scoring and weight estimation of horses. Equine Veterinary Journal 20 (1):41-45.

Carter RA, Geor RJ, Staniar WB, Cubitt TA, Harris PA. 2009a. Apparent adiposity assessed by standardised scoring systems and morphometric measurements in horses and ponies. Veterinary journal (London, England: 1997) 179 (2):204-210.

Carter RA, McCutcheon L, George LA, Smith TL, Frank N, Geor RJ. 2009b. Effects of diet-induced weight gain on insulin sensitivity and plasma hormone and lipid concentrations in horses. Journal of the American Veterinary Medical Association 235 (7):854.

Cash JL, Hart R, Russ A, Dixon JPC, Colledge WH, Doran J, Hendrick AG, Carlton MBL, Greaves DR. 2008. Synthetic chemerin-derived peptides suppress inflammation through ChemR23. The Journal of experimental medicine 205 (4):767-775.

Chakaroun R, Raschpichler M, Kloting N, Oberbach A, Flehmig G, Kern M, Schon MR, Shang E, Lohmann T, Dressler M, Fasshauer M, Stumvoll M, Bluher M. 2012. Effects of weight loss and exercise on chemerin serum concentrations and adipose tissue expression in human obesity. Metabolism: clinical and experimental 61 (5):706-714.

Chameroy KA, Frank N, Elliott SB, Boston RC. 2011. Effects of a supplement containing chromium and magnesium on morphometric measurements, resting glucose, insulin concentrations and insulin sensitivity in laminitic obese horses. Equine Veterinary Journal 43 (4):494-499.

Cortez-Pinto H, Camilo ME, Baptista A, Oliveira AG de, De Moura. M. C. 1999. Non-alcoholic fatty liver: another feature of the metabolic syndrome? Clinical Nutrition 18 (6):353-358. 
501

502

503

504

505

506

507

508

509

510

511

512

513

514

515

516

517

518

519

520

521

522

523

524

525

526

527

528

529

530

531

532

533

534

535

536

537

538

539

540

541

Deng Y, Wang H, Lu Y, Liu S, Zhang Q, Huang J, Zhu R, Yang J, Zhang R, Di Zhang, Shen W, Ning G, Yang Y. 2013. Identification of chemerin as a novel FXR target gene down-regulated in the progression of nonalcoholic steatohepatitis. Endocrinology 154 (5):1794-1801.

Devers MC, Campbell S, Shaw J, Zimmet P, Simmons D. 2008. Should liver function tests be included in definitions of metabolic syndrome? Evidence from the association between liver function tests, components of metabolic syndrome and prevalent cardiovascular disease. Diabetic medicine: $a$ journal of the British Diabetic Association 25 (5):523-529.

Döcke S, Lock JF, Birkenfeld AL, Hoppe S, Lieske S, Rieger A, Raschzok N, Sauer IM, Florian S, Osterhoff MA, Heller R, Herrmann K, Lindenmüller S, Horn P, Bauer M, Weickert MO, Neuhaus P, Stockmann M, Möhlig M, Pfeiffer AFH, Loeffelholz $C$ von. 2013. Elevated hepatic chemerin mRNA expression in human non-alcoholic fatty liver disease. European journal of endocrinology 169 (5):547-557.

Eiler H, Frank N, Andrews FM, Oliver JW, Fecteau KA. 2005. Physiologic assessment of blood glucose homeostasis via combined intravenous glucose and insulin testing in horses. American Journal of Veterinary Research 66 (9):1598-1604.

Flachowsky G, Kamphues J, Rodehutscord M, Schenkel H, Staudacher W, Südekum KH, Susenbeth A, Windisch W, Coenen M, Kienzle E, Zeyner A. 2014. Empfehlungen zur Energie- und Nährstoffversorgung von Pferden 11.

Frank N, Geor RJ, Bailey SR, Durham AE, Johnson PJ. 2010. Equine metabolic syndrome. Journal of veterinary internal medicine 24 (3):467-475.

Gehlen H, May A, Venner M. 2010. Lebererkrankungen beim Pferd. Pferdeheilkunde 26 (5):668-679.

Gerspach C, Imhasly S, Klingler R, Hilbe M, Hartnack S, Ruetten M. 2017. Variation in fat content between liver lobes and comparison with histopathological scores in dairy cows with fatty liver. BMC veterinary research 13 (1):98.

Glatz JFC, Van der Vusse GJ, Veerkamp JH. 1988. Fatty Acid-Binding Proteins and Their Physiological Significance. News in Physiological Sciences 3:41-43.

Goralski KB, McCarthy TC, Hanniman EA, Zabel BA, Butcher EC, Parlee SD, Muruganandan S, Sinal CJ. 2007. Chemerin, a novel adipokine that regulates adipogenesis and adipocyte metabolism. The Journal of biological chemistry 282 (38):28175-28188.

Haeusler RA, Astiarraga B, Camastra S, Accili D, Ferrannini E. 2013. Human insulin resistance is associated with increased plasma levels of $12 \alpha$-hydroxylated bile acids. Diabetes 62 (12):4184-4191.

Higuchi N, Kato M, Tanaka M, Miyazaki M, Takao S, Kohjima M, Kotoh K, Enjoji M, Nakamuta M, Takayanagi R. 2011. Effects of insulin resistance and hepatic lipid accumulation on hepatic mRNA expression levels of apoB, MTP and L-FABP in non-alcoholic fatty liver disease. Experimental and Therapeutic Medicine 2 (6):1077-1081.

Hotamisligil GS, Shargill NS, Spiegelman BM. 1993. Adipose Expression of Tumor Necrosis Factor-x: Direct Role in Obesity-Linked Insulin Resistance. Science 259 (5091):87-91.

Johnson PJ, Wiedmeyer CE, LaCarrubba A, Ganjam VKS, Messer NT. 2010. Laminitis and the equine metabolic syndrome. The Veterinary clinics of North America. Equine practice 26 (2):239-255.

Kechagias S, Ernersson A, Dahlqvist O, Lundberg P, Lindström T, Nystrom FH. 2008. Fast-food-based hyper-alimentation can induce rapid and profound elevation of serum alanine aminotransferase in healthy subjects. Gut 57 (5):649-654. 
542

543

544

545

546

547

548

549

550

551

552

553

554

555

556

557

558

559

560

561

562

563

564

565

566

567

568

569

570

571

572

573

574

575

576

577

578

579

580

581

582

583

Köller G, Gieseler T, Schusser GF. 2014. Hämatologische und blutchemische Referenzbereiche bei Pferden unterschiedlicher Rasse und Altersgruppen basierend auf neuesten labordiagnostischen Methoden. Pferdeheilkunde 30 (4):381-393.

Krautbauer S, Wanninger J, Eisinger K, Hader Y, Beck M, Kopp A, Schmid A, Weiss TS, Dorn C, Buechler C. 2013. Chemerin is highly expressed in hepatocytes and is induced in non-alcoholic steatohepatitis liver. Experimental and Molecular Pathology 95 (2):199-205.

Lonardo A, Ballestri S, Marchesini G, Angulo P, Loria P. 2015. Nonalcoholic fatty liver disease: a precursor of the metabolic syndrome. Digestive and liver disease: official journal of the Italian Society of Gastroenterology and the Italian Association for the Study of the Liver 47 (3):181-190.

Luangsay S, Wittamer V, Bondue B, Henau O de, Rouger L, Brait M, Franssen J-D, Nadai P de, Huaux F, Parmentier M. 2009. Mouse ChemR23 is expressed in dendritic cell subsets and macrophages, and mediates an anti-inflammatory activity of chemerin in a lung disease model. Journal of immunology (Baltimore, Md.: 1950) 183 (10):6489-6499.

Ma H, Patti ME. 2014. Bile acids, obesity, and the metabolic syndrome. Best practice \& research. Clinical gastroenterology 28 (4):573-583.

Meijer VE de, Le HD, Meisel JA, Akhavan Sharif MR, Pan A, Nosé V, Puder M. 2010. Dietary fat intake promotes the development of hepatic steatosis independently from excess caloric consumption in a murine model. Metabolism: clinical and experimental 59 (8):1092-1105.

Pardina E, Baena-Fustegueras JA, Llamas R, Catalán R, Galard R, Lecube A, Fort JM, Llobera M, Allende H, Vargas V, Peinado-Onsurbe J. 2009. Lipoprotein Lipase Expression in Livers of Morbidly Obese Patients Could be Responsible for Liver Steatosis. Obesity Surgery 19 (5):608-616.

Pfaffl MW, Tichopad A, Prgomet C, Neuvians P. 2004. Determination of stable housekeeping genes, differentially regulated target genes and sample integrity: BestKeeper \&\#x2013; Excel-based tool using pair-wise correlations. Biotechnology Letters 26:509-515.

Pohl R, Haberl EM, Rein-Fischboeck L, Zimny S, Neumann M, Aslanidis C, Schacherer D, Krautbauer S, Eisinger K, Weiss TS, Buechler C. 2017. Hepatic chemerin mRNA expression is reduced in human nonalcoholic steatohepatitis. European journal of clinical investigation 47 (1):7-18.

Qu H, Deng H, Hu Z. 2013. Plasma progranulin concentrations are increased in patients with type 2 diabetes and obesity and correlated with insulin resistance. Mediators of inflammation 2013:360190.

Schmidt ES, Schmidt FW. 1988. Glutamate dehydrogenase: biochemical and clinical aspects of an interesting enzyme. Clinica Chimica Acta 43:43-56.

Shi J, Zhang Y, Gu W, Cui B, Xu M, Yan Q, Wang W, Ning G, Hong J. 2012. Serum liver fatty acid binding protein levels correlate positively with obesity and insulin resistance in Chinese young adults. PloS one 7 (11):e48777.

Siegers EW, Ruijter-Villani M de, van Doorn DA, Stout TAE, Roelfsema E. 2018. Ultrasonographic measurements of localized fat accumulation in Shetland pony mares fed a normal v. a high energy diet for 2 years. Animal 12 (8):1602-1610.

Sookoian S, Castano GO, Scian R, Fernandez Gianotti T, Dopazo H, Rohr C, Gaj G, San Martino J, Sevic I, Flichman D, Pirola CJ. 2016. Serum aminotransferases in nonalcoholic fatty liver disease are a signature of liver metabolic perturbations at the amino acid and Krebs cycle level. The American journal of clinical nutrition 103 (2):422-434.

PeerJ reviewing PDF | (2019:01:34571:1:1:NEW 16 Apr 2019) 
584

585

586

587

588

589

590

591

592

593

594

595

596
Vick MM, Adams AA, Murphy BA, Sessions DR, Horohov DW, Cook RF, Shelton BJ, Fitzgerald BP. 2007. Relationships among inflammatory cytokines, obesity, and insulin sensitivity in the horse. Journal of animal science 85 (5):1144-1155.

Vozarova B, Weyer C, Hanson K, Tataranni PA, Bogardus C, Pratley RE. 2001. Circulating interleukin-6 in relation to adiposity, insulin action, and insulin secretion. Obesity research 9 (7):414-417.

Weigert J, Neumeier M, Wanninger J, Filarsky M, Bauer S, Wiest R, Farkas S, Scherer MN, Schäffler A, Aslanidis C, Schölmerich J, Buechler C. 2010. Systemic chemerin is related to inflammation rather than obesity in type 2 diabetes. Clinical endocrinology 72 (3):342-348.

Yoshimura T, Oppenheim JJ. 2008. Chemerin reveals its chimeric nature. The Journal of experimental medicine 205 (10):2187-2190.

Zhang L, Ma X, Jiang Z, Zhang K, Zhang M, Li Y, Zhao X, Xiong H. 2015. Liver enzymes and metabolic syndrome: a large-scale case-control study. Oncotarget 6 (29):26782-26788. 
Figure 1 (on next page)

Serum liver enzyme activities and serum BA concentrations in ponies and horses during two years of excess energy intake

Serum ALP activities (A), serum GLDH activities (B), serum AST activities (C), serum bile acids

(D) and serum GGT activities (E) in ponies ( $N=10)$ (filled circles) and horses $(N=9)$

(triangles) at $\mathrm{t} 0, \mathrm{t} 1, \mathrm{t} 2, \mathrm{t} 3, \mathrm{t} 4$ and $\mathrm{t} 5$ (reported as medians (filled circles or triangles),

25th/75th percentiles (whiskers), outliers (blank circles), and extreme values (asterisk)); + significantly different from $\mathrm{t} 0$; $\square$ significantly different from $\mathrm{t} 2$; \# significantly different between ponies and horses at the certain time point 
Figure 2 (on next page)

Hepatic chemerin mRNA level in ponies and horses

Fold changes in the hepatic levels of the chemerin mRNA at t0 (white), t2 (light gray) and t5 (dark gray) in ponies $(\mathrm{N}=10)$ and horses $(\mathrm{N}=9)$ (reported as medians (squares), 25th/75th percentiles (boxes), minimum and maximum values (whiskers), and outliers (circles)); significant differences are indicated by *, no significant differences between ponies and horses were observed. 


\section{Table $\mathbf{1}$ (on next page)}

Estimated dietary intake per equine on a daily basis and calculated dietary composition during the whole feeding period (data are presented as mean \pm SD). 
1 Table 1. Estimated dietary intake per equine on a daily basis and calculated dietary composition

2 during the whole feeding period (data are presented as mean $\pm S D$ ).

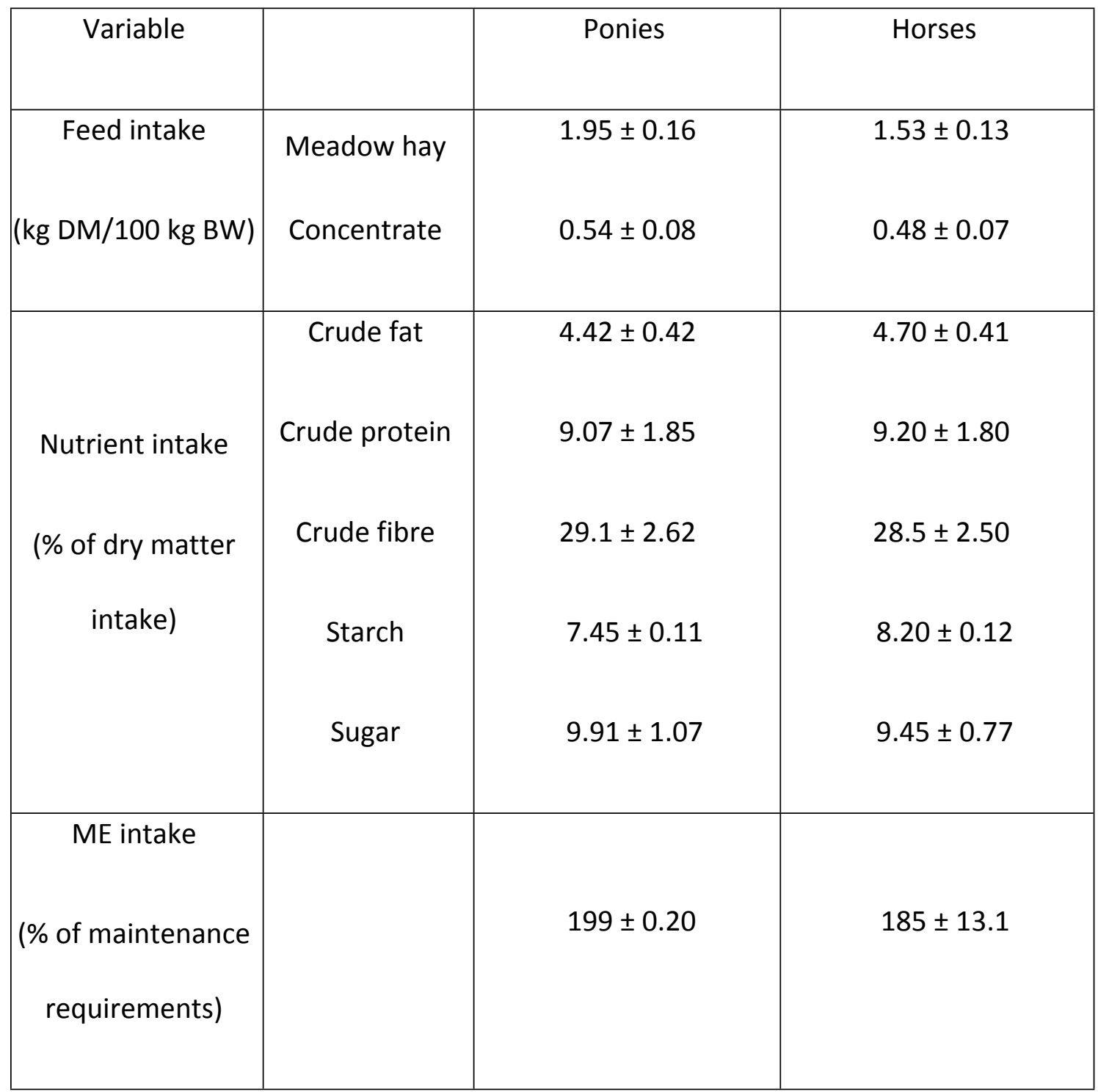

3

4 


\section{Table 2 (on next page)}

Primer sequences used to analyze the levels of the genes of interest and reference genes. Five qPCR primers were newly designed and 5 primers were obtained from published data.

"Designed using http://primer3.ut.ee/. The specific equine cDNA sequences were provided by http://www.ensembl.org/index.html and the generated primers were validated in http://eu.idtdna.com/calc/analyzer to confirm the absence of hairpins, homodimers and heterodimers. The designed primers were created with two different modifications for each gene of interest and the more suitable primer was selected in preliminary tests. Primers were synthesized by biomers.net $\mathrm{GmbH}$. 
1 Table 2. Primer sequences used to analyze the levels of the genes of interest and reference

2 genes. Five qPCR primers were newly designed and 5 primers were obtained from published

3 data.

\begin{tabular}{|c|c|c|}
\hline & Forward $\left(5^{\prime}-3^{\prime}\right)$ & Reverse $\left(3^{\prime}-5^{\prime}\right)$ \\
\hline $\begin{array}{l}\text { IL-6 (Ungru et al., } \\
\text { 2012) }\end{array}$ & ССАССТCAAATGGACCACTACTC & TTTTCAGGGCAGAGATTTTGC \\
\hline $\begin{array}{l}\text { TNFa (Figueiredo } \\
\text { et al., 2009) }\end{array}$ & AAAGGACATCATGAGCACTGAAAG & GGGCCCCCTGCCTTCT \\
\hline $\begin{array}{l}\text { CD68 (Ungru et } \\
\text { al., 2012) }\end{array}$ & CTTTGGGCCAAGTTTCTCTTGT & AAGAGGCCGAGGAGGATCAG \\
\hline $\begin{array}{l}\text { HPRT1 (Bogaert } \\
\text { et al., 2006) }\end{array}$ & GGCAAAACAATGCAAACCTT & CAAGGGCATATCCTACGACAA \\
\hline $\begin{array}{l}\text { RPL32 (Bogaert et } \\
\text { al., 2006) }\end{array}$ & AGCCATCTACTCGGCGTCA & TCCAATGCCTCTGGGTTTC \\
\hline IL-1 $\beta^{\#}$ & CGGCAATGAGAATGACCTGT & GCTTCTCCACAGCCACAATG \\
\hline $\mathrm{LPL}^{\#}$ & ATTGTGGTGGACTGGCTGT & GCTCCAAGGCTGTATCCCAA \\
\hline FABP1 \# & CAAGATCACCATCACCACAGG & GTCACAGACTTGATGCCTTTGA \\
\hline Chemerin $\#$ & CATGGGAGGAAGCGGAAATG & CAGCTGAGCCTGTGTCTCTA \\
\hline NF-KB \# & GCTTTGTGACAAGGTGCAGA & ACGATCATCTGTGTCTGGCA \\
\hline
\end{tabular}

$4 \quad$ \# Designed using http://primer3.ut.ee/. The specific equine cDNA sequences were provided by

5 http://www.ensembl.org/index.html and the generated primers were validated in

6 http://eu.idtdna.com/calc/analyzer to confirm the absence of hairpins, homodimers and 
7 heterodimers. The designed primers were created with two different modifications for each

8 gene of interest and the more suitable primer was selected in preliminary tests. Primers were

9 synthesized by biomers.net $\mathrm{GmbH}$.

10

11

12

13

14

15

16

17

18

19

20

21

22

23

References

Bogaert L, van Poucke M, Baere C de, Peelman L, Gasthuys F, Martens A. 2006. Selection of a set of reliable reference genes for quantitative real-time PCR in normal equine skin and in equine sarcoids. BMC Biotechnology 6:24.

Figueiredo MD, Salter CE, Andrietti ALP, Vandenplas ML, Hurley DJ, Moore JN. 2009. Validation of a reliable set of primer pairs for measuring gene expression by real-time quantitative RT-PCR in equine leukocytes. Veterinary immunology and immunopathology 131 (1-2):65-72.

Ungru J, Blüher M, Coenen M, Raila J, Boston R, Vervuert I. 2012. Effects of body weight reduction on blood adipokines and subcutaneous adipose tissue adipokine mRNA expression profiles in obese ponies. The Veterinary record 171 (21):528. 


\section{Table 3 (on next page)}

BCS and CNS in ponies and horses during two years of excess energy intake (data are presented as medians and 25th/75th percentiles)

Different superscript letters indicate significant differences within a row. 
1 Table 3. BCS and CNS in ponies and horses during two years of excess energy intake (data are

2 presented as medians and 25th/75th percentiles)

\begin{tabular}{|l|l|l|l|l|}
\hline Breed & Score & t0 & t2 & t5 \\
\hline \multirow{3}{*}{ Ponies } & BCS & $2.3(1.2 / 3.4)^{\mathrm{a}}$ & $3.6(3.4 / 3.7)^{\mathrm{a}}$ & $3.9(3.7 / 4.2)^{\mathrm{b}}$ \\
& & & & \\
\cline { 2 - 5 } & CNS & $2.5(0.8 / 3)^{\mathrm{a}}$ & $2.8(2.5 / 3.0)^{\mathrm{a}}$ & $3.5(3.3 / 4.0)^{\mathrm{b}}$ \\
\hline \multirow{3}{*}{ Horses } & BCS & $2.7(2.1 / 3.2)^{\mathrm{ab}}$ & $3.6(3.5 / 3.6)^{\mathrm{b}}$ & $3.8(3.7 / 3.9)^{\mathrm{c}}$ \\
& & & & $3.5(3.5 / 4.0)^{\mathrm{c}}$ \\
\cline { 2 - 5 } & CNS & $2(1.8 / 2.3)^{\mathrm{a}}$ & $2.8(2.8 / 3.0)^{\mathrm{b}}$ & \\
\hline
\end{tabular}

3 Different superscript letters indicate significant differences within a row.

4 


\section{Table 4(on next page)}

Plasma glucose (mmol/L), serum insulin $(\mu \mathrm{U} / \mathrm{mL})$, serum NEFA ( $\mu \mathrm{mol} / \mathrm{L})$ and serum TG $(\mathrm{mmol} / \mathrm{L})$ concentrations recorded in ponies and horses during two years of excess energy intake (data are presented as means \pm SD).

Different superscript letters indicate significant differences within a row. 
1 Table 4. Plasma glucose $(\mathrm{mmol} / \mathrm{L})$, serum insulin $(\mu \mathrm{U} / \mathrm{mL})$, serum NEFA $(\mu \mathrm{mol} / \mathrm{L})$ and serum TG

$2(\mathrm{mmol} / \mathrm{L})$ concentrations recorded in ponies and horses during two years of excess energy

3 intake (data are presented as means $\pm S D$ ).

\begin{tabular}{|c|c|c|c|c|c|c|}
\hline & t0 & & t2 & & t5 & \\
\hline & Ponies & Horses & Ponies & Horses & Ponies & Horses \\
\hline $\begin{array}{l}\text { Glucose } \\
\text { (mmol/L) }\end{array}$ & $3.53 \pm 0.64^{a}$ & $4.08 \pm 0.21^{b}$ & $3.93 \pm 0.38^{a b}$ & $4.52 \pm 0.23^{b}$ & $4.34 \pm 0.86^{b}$ & $4.41 \pm 0.48^{b}$ \\
\hline $\begin{array}{l}\text { Insulin } \\
(\mu \mathrm{U} / \mathrm{mL})\end{array}$ & $4.26 \pm 1.36^{\mathrm{ac}}$ & $6.32 \pm 2.35^{c}$ & $7.93 \pm 5.75^{\mathrm{abc}}$ & $9.3 \pm 3.18^{a b c}$ & $13.9 \pm 14.9^{b}$ & $15.1 \pm 10.3^{b}$ \\
\hline $\begin{array}{l}\text { NEFA } \\
(\mu \mathrm{mol} / \mathrm{L})\end{array}$ & $119 \pm 117^{a}$ & $337 \pm 381^{b}$ & $208 \pm 168^{a b}$ & $211 \pm 89^{a b}$ & $352 \pm 141^{b}$ & $247 \pm 87^{a b}$ \\
\hline $\begin{array}{l}\text { TG } \\
(\mathrm{mmol} / \mathrm{L})\end{array}$ & $0.49 \pm 0.19^{a}$ & $0.27 \pm 0.09^{b c}$ & $0.41 \pm 0.31^{\mathrm{ab}}$ & $0.24 \pm 0.05^{c}$ & $0.42 \pm 0.2^{\mathrm{ab}}$ & $0.31 \pm 0.08^{b c}$ \\
\hline
\end{tabular}

4 Different superscript letters indicate significant differences within a row. 


\section{Table 5 (on next page)}

Staging of hepatic steatosis in ponies and horses during two years of excess energy intake (data are presented as numbers and as percentages of the breed). 
1 Table 5. Staging of hepatic steatosis in ponies and horses during two years of excess energy

2 intake (data are presented as numbers and as percentages of the breed).

\begin{tabular}{|c|c|c|c|c|}
\hline Steatosis & t0 & & t5 & \\
\hline & Ponies & Horses & Ponies & Horses \\
\hline 0 & $\begin{array}{l}8 / 10 \\
(80 \%)\end{array}$ & $\begin{array}{l}6 / 9 \\
(66.6 \%)\end{array}$ & $\begin{array}{l}6 / 10 \\
(60 \%)\end{array}$ & $\begin{array}{l}8 / 9 \\
\text { (88.9\%) }\end{array}$ \\
\hline 1 & $\begin{array}{l}2 / 10 \\
(20 \%)\end{array}$ & $\begin{array}{l}3 / 9 \\
(33.3 \%)\end{array}$ & $\begin{array}{l}2 / 10 \\
(20 \%)\end{array}$ & $\begin{array}{l}1 / 9 \\
(11.1 \%)\end{array}$ \\
\hline 2 & $\begin{array}{l}0 / 10 \\
(0 \%)\end{array}$ & $\begin{array}{l}0 / 9 \\
(0 \%)\end{array}$ & $\begin{array}{l}1 / 10 \\
(10 \%)\end{array}$ & $\begin{array}{l}0 / 9 \\
(0 \%)\end{array}$ \\
\hline 3 & $\begin{array}{l}0 / 10 \\
(0 \%)\end{array}$ & $\begin{array}{l}0 / 9 \\
(0 \%)\end{array}$ & $\begin{array}{l}1 / 10 \\
(10 \%)\end{array}$ & $\begin{array}{l}0 / 9 \\
(0 \%)\end{array}$ \\
\hline
\end{tabular}

3 


\section{Table 6(on next page)}

Correlations between the level of the LPL and chemerin mRNAs with serum BA concentrations, hepatic lipid contents, BCS, CNS, and the levels of the CD68 and NF-KB mRNAs.

$r^{1}=$ Spearman's correlation coefficient 
1 Table 6. Correlations between the level of the LPL and chemerin mRNAs with serum BA

2 concentrations, hepatic lipid contents, BCS, CNS, and the levels of the CD68 and NF-KB mRNAs.

\begin{tabular}{|c|c|c|c|c|}
\hline \multirow{2}{*}{ Variables } & \multicolumn{2}{|c|}{ Ponies $(\mathrm{N}=10 ; \mathrm{n}=30)$} & \multicolumn{2}{|c|}{ Horses $(N=9 ; n=27)$} \\
\hline & $r^{1}$ & $P$ value & $r^{1}$ & $P$ value \\
\hline Chemerin $\times \mathrm{BCS}$ & 0.6 & $<0.001$ & 0.5 & 0.005 \\
\hline Chemerin $\times$ CNS & 0.6 & $<0.001$ & 0.6 & 0.001 \\
\hline Chemerin $x$ NF-KB & -0.2 & 0.2 & -0.6 & 0.002 \\
\hline $\mathrm{LPL} \times \mathrm{BA}$ & 0.4 & 0.02 & -0.3 & 0.2 \\
\hline LPL x CD68 & 0.4 & 0.02 & 0.6 & $<0.001$ \\
\hline LPL $x$ hepatic lipid content & 0.4 & 0.02 & 0.01 & 0.9 \\
\hline
\end{tabular}

$r^{1}=$ Spearman's correlation coefficient 